\title{
Jarosław Wierzbiński
}

\section{WYKAZ PUBLIKACJI}

\section{DRUKI ZWARTE}

1. Monografia: Stylistyczny fenomen języka artystycznego Michała Zoszczenki, Łódź: Wyd. UŁ, 1999, ss. 176 (rozprawa habilitacyjna).

Recenzje:

Л. А. Введенская, «Филологический вестник Ростовского государственного университета», Ростов-на-Дону 1999, № 3, s. 72-73.

К. Попов, „Foreign Language Teaching Journal / Чуждоезиково обучение”, Sofia 1999, nr 4, s. 79-80.

Tegoż, „Russian Language Journal / Русский язык”, Michigan (Michigan State University) 2000, No. 177-179, Vol. 54, s. 273-275.

T. Żeberek, „Slavia Orientalis” 2000, nr 1, s. 129.

В. Гаврюшенко, „Przegląd Rusycystyczny” 2000, z. 3, s. 119-122.

Tejże, „Kritikon Litterarum” 29, Mertert/Luxbg. und Trier 2002, Heft 1-2, s. 50-53.

Л. Я. Костючук, „Stylistyka” 2001, t. X: Styl i humor, s. 526-530.

P. Czerwiński, „Respectus Philologicus”, Kaunas 2002, nr 2, s. 188-189.

2. Monografia: Языковой монументализм в России XX века (Диахроническая экспликация научных парадигм) / Monumentalizacja języka w Rosji XX wieku (Eksplikacja diachroniczna paradygmatów naukowych), Łódź: Wyd. UŁ, 2012, ss. 263 (książka profesorska).

Recenzje:

Э. Лассан, „Respectus Philologicus”, Vilnius-Kaunas-Kielce 2013, nr 23, s. 218-220.

B. Rycielska, „Slavia Orientalis” 2013, t. LXI, nr 4, s. 652-655.

К. Попов, „Foreign Language Teaching / Чуждоезиково обучение”, Sofia 2014, nr 1, s. 75-79.

3. Monografia: Семантика идиостиля А.П. Чехова (на материале антонимических образований и смежных явлений) / Semantyka idiolektu Antoniego Czechowa (na materiale relacji antonimicznych i zjawisk pokrewnych), Łódź: Wyd. Primum Verbum, 2013, ss. 211.

Recenzje:

Г. Гочев, „Проглас. Филологичєско списаниє”, Велико Търново 2014, кн. 2, s. 122-124.

В.С. Картавенко, «Известия Смоленского государственного университета» 2015, № 1 (29), s. 462-467.

4. Skrypt: Морфемика. Морфонология. Словообразование (учебное пособие по русскому языку) / Morfemika. Morfonologia. Stowotwórstwo (skrypt do nauki języka rosyjskiego), Тернополь: Изд-во „Studia Methodologica”, 2009, ss. 58. 
Recenzje:

B. Rycielska, „Przegląd Rusycystyczny” 2010, z. 3, s. 110-111.

Т. Коновалова, „Acta Universitatis Lodziensis. Folia Linguistica Rossica” 2011, z. 7, s. 63.

Н.Ж. Шаймерденова, М.А. Бурибаева, „Вестник Кокшетауского государственного университета им. Ш. Уалиханова. Серия «Филология»”, Кокшетау 2012, № 1-2, s. 205-206.

5. Podręcznik: Semantyka słowa. Kategorie semantyki leksykalnej (podręcznik do nauki języka rosyjskiego) / Значение слова. Категории лексической семантики (учебное пособие по русскому языку, Łódź: Wyd. Primum Verbum, 2011, ss. 95.

Recenzje:

С. Димитрова, „Foreign Language Teaching Journal / Чуждоезиково обучение”, Sofia 2011, nr 2, s. 61-64.

М.Б. Амалбекова, «Тіл және әдебиет / Язык и литература / Language and literature», Алматы 2012, № 1, s. 72-73.

6. Autoreferat rozprawy': Антонимо-синонимические отношения в лексике (на материале художественных произведений А. П. Чехова). Автореферат диссертации на соискание ученой степени кандидата филологических наук, Ростов-на-Дону: Изд-во РГУ 1984, ss. 26.

\section{PRACE REDAKCYJNE}

1. „Beiträge zur Slavistik“, t. XXXIX: Textsemantik und Textstilistik, Frankfurt am Main-BerlinBern-New York-Paris-Wien: Peter Lang 1999, ss. 328 (współredaktor: H. Jelitte).

2. „Beiträge zur Slavistik“, t. XLVII: Slovo v tekste, perevode i slovare, Frankfurt am Main-BerlinBern-Bruxelles-New York-Oxford-Wien: Peter Lang 2002, ss. 497 (współredaktor: K.Bajor).

Recenzja:

Nigel Cotteri (University of Sheffeld), "Slavonica" 2005, t. 11, nr 1, s. 99.

3. „Acta Universitatis Lodziensis. Folia Linguistica Rossica”, z. 1: Funkcjonowanie środków językowo-stylistycznych $w$ tekstach mówionych i pisanych, 2003, ss. 177. http://linguisticarossica.cba.pl/file/FOLIA_LINGUISTICA_ROSSICA_1.pdf http://dspace.uni.lodz.pl:8080/xmlui/ handle/11089/3954

4. Aktualne problemy semantyki i stylistyki tekstu (studia opisowe i komparatywne), Łódź: Wyd. UŁ, 2004, ss. 275.

Recenzje i opinie:

О. Жолобов, «Казанский университет» 2003, № 17-18, s. 6.

М. Лабащук, „Przegląd Rusycystyczny” 2004, z. 1, s. 141-143.

Редакція альманаху, «StudiaMethodologica», випуск 14, Тернопіль 2004, s . 199-201.

5. „Acta Universitatis Lodziensis. Folia Linguistica Rossica”, z. 2: Język - struktura - styl. Wspótczesne kierunki badań lingwistycznych, 2006, ss. 194 (współredaktor: A. Ginter). http:// rossica.online.uni.lodz.pl/index.php/content,article, 23

6. „Acta Universitatis Lodziensis. Folia Linguistica Rossica”, z. 3: Semantyka i pragmatyka tekstu, 2007, ss. 200 (współredaktor: M. Wingender). http://rossica.online.uni.lodz.pl/index.php/ content,article, 22

${ }^{1}$ Tekst pracy doktorskiej: Антонимо-синонимические отношения в лексике (на материале художественных произведений А. П. Чехова. Диссертация на соискание ученой степени кандидата филологических наук, Ростов-на-Дону 1983, 326 s. (maszynopis w Bibliotece Uniwersytetu Rostowskiego). 
7. „Acta Universitatis Lodziensis. Folia Linguistica Rossica”, z. 4: Język i kultura, 2008, ss. 190. http://rossica.online.uni.lodz.pl/index.php/content,article,29

8. E. Nevzorova-Kmech, Polsko-rosyjski słownik frazeologiczny gwary młodzieżowej / Польско-русский фразеологический словарь молодежного сленга, Łódź: Wyd. Primum Verbum, 2010, ss. 259.

9. „Acta Universitatis Lodziensis. Folia Linguistica Rossica”, z. 6: Język - komunikacja międzykulturowa - tekst i jego interpretacja, 2010, ss. 210 (współredaktor: Th. Daiber).

10. Теоретические и прикладные аспекты изучения семантики и стилистики текста / Теоretyczne i praktyczne aspekty badań semantyki i stylistyki tekstu, Łódź: Primum Verbum, 2012, ss. 246 (współredaktorzy: Th. Daiber, G. Gochev, I. Zlatev).

11. Язык и стиль литературных и нелитературных текстов / Język i styl tekstów literackich i nieliterackich, Łódź: Primum Verbum, 2012, ss. 232 (współredaktorzy: A. Tsoi, A. Ginter, A. Kamińska).

12. „Acta Universitatis Lodziensis. Folia Linguistica Rossica”, z. 8: W kręgu zagadnień semantycznych, kulturologicznych i pragmatycznych, 2012, ss. 118 (współredaktor: A. Piasecka). http://rossica.online.uni.lodz.pl/index.php/content,article,29

\section{ARTYKULY}

1. Методика семного анализа и сферы его применения при изучении синонимо-антонимических отношений. Artykuł zdeponowany 11.08 .1982 pod nr. 10762 w Instytucie Informacji Naukowej Akademii Nauk w Moskwie. Bibliograficzny opis artykułu opublikowany w biuletynie «Новая советская литература по общественным наукам. Языкознание», Москва 1983, № 1, 24 s. maszynopisu.

2. Семантический анализ антонимо-синонимических парадигм. Artykuł zdeponowany 11.08.1982 pod nr. 10761 w Instytucie Informacji Naukowej Akademii Nauk w Moskwie. Bibliograficzny opis artykułu opublikowany w biuletynie «Новая советская литература по общественным наукам. Языкознание», Москва 1983, № 1, 23 s. maszynopisu.

3. Из наблюдений над стилем «Тихого Дона» М. Шолохова, „Acta Universitatis Lodziensis. Folia Linguistica" 1983, z. 5, s. 181-189.

4. Функционирование антонимов в художественной речи А.П. Чехова, „Przegląd Rusycystyczny" 1987, z. 3-4, s. 151-162.

5. Квопросуосемантическом анализе антонимов врусскомязыкена фонелексикографической практики, „Acta Universitatis Lodziensis. Folia Linguistica” 1989, z. 20, s. 119-129.

6. К вопросу о семантике противопоставляемых синонимов в русском языке, „Болгарская русистика", София 1989, № 6, s. 32-40.

7. Своеобразие парадигмы с доминантой «хороший-плохой» (на материале произведений А. П. Чехова и словарей русского языка), „Acta Universitatis Lodziensis.Folia Linguistica” 1989, z. 21, s. 57-67.

8. Заметки о языке и стиле Михаила Зощенко (лингвистический аспект), „Болгарская русистика”, София 1991, № 4, s. 31-41.

9. Z badań nad problematyka antonimiczna $w$ radzieckiej literaturze lingwistycznej, „Acta Universitatis Lodziensis. Folia Linguistica" 1992, z. 26, s. 43-61.

10. Семантическая организация чеховских юморесок «И то и сё (Поэзия и проза)», „Болгарская русистика”, София 1992, № 2, s. 28-34.

11. Michait Zoszczenko - burzyciel stalinowskiego „sacrum”, „Literatura na Świecie” 1993 , nr 10, s. 196-207 (współautor: T. Stepnowska). 
12. Стилистическое использование антонимов, несоотносительных в понятийном плане, в художественной речи А. П. Чехова, „Foreign Language Teaching Journal / Чуждоезиково обучение", Sofia 1994, nr 1, s. 10-16.

13. Иноязычные вкрапления в русской художественной литератературе (на материале произведений Михаила Зощенко), „Beiträge zur Slavistik”, t. XXVII: Innerslavischer undslavisch-deutscher Sprachvergleich. H.Jelitte, T.P.Troškina (Hrsg.), Frankfurt am Main-Berlin-Bern-New York-Paris-Wien 1995, s. 241-253.

14. Język utworów Michaiła Zoszczenki w konfrontacji przekładowej, „Slavia Orientalis” 1995, nr 2, t. XLIV, s. 239-250.

15. Projekcja "Ruskiej Prawdy” w ,Niebieskiej księdze” Michała Zoszczenki (aspekt lingwistyczny), „Acta Universitatis Lodziensis. Folia Linguistica” 1995, z. 33, s. 91-99.

16. Слово в структуре художественных текстов Михаила Зощенко. Языковые деформаиии, „Slavica Quinqueecclesiensia” I, Pécs 1995, s. 163-173.

17. Семантика заглавных антонимов в сочинениях А.П. Чехова, „Foreign Language Teaching Journal / Чуждоезиково обучение", Sofia 1995, nr 3, s. 4-11.

18. Антонимы в заглавиях чеховских произведений, „Russian Language Journal / Русский язык”, East Lansing, Michigan (Michigan State University) 1995, No. 162-164, Vol. XLIX, s. 295-306.

19. «Русская Правда» в «Голубой книге» Михаила Зощенко (Лингвистический аспект), „Beiträge zur Slavistik”, t. XXIX: Das Adjectiv im Russischen. Geschichte, Strukturen, Funktionen. H. Jelitte, E.A. Balalykina (Hrsg.), Frankfurt am Main-Berlin-Bern-New York-Paris -Wien 1996, s. 147-156.

20. Manifestowanie się nowomowy w tekstach Michaiła Zoszczenki, „Acta Universitatis Lodziensis. Folia Linguistica" 1996, z. 35, s. 87-98.

21. Выбор технических средств с учетом специфики контингента, обучаемого иностранному языку, [w:] Nowe elementy teorii i praktyki opisu i dydaktyki nauczania języka rosyjskiego. Materiaty konferencji naukowo-metodycznej w Warszawie 22-23 maja 1997 r., Warszawa 1997, s. 269-276 (współautor: S. Jurkin).

22. О семантике лексических контрастов в художественных произведениях А. П. Чехова (на материале адъективных образований), [w:] Florilegium Slavicum: liber adhonorandum Herbert Jelitte. E.Bogdanova, M.Sobieroj (Hrsg.), Frankfurt am Main-Berlin-Bern-New York-Paris-Wien 1998, s. 313-324.

23. Языковое своеобразие произведений Михаила Зощенко, „Beiträge zur Slavistik”, t. XXXVII: Slavistische Studien zum XII. Internationalen Slavistenkongreß in Krakau 1998. H. Jelitte (Hrsg.), Frankfurt am Main-Berlin-Bern-New York-Paris-Wien 1998, s. 301-308.

24. Как заголовок сигнализирует о содержании произведения, «Русская словесность в школах Украины», Киев 1998, № 4, s. 40-41.

25. Борис Шекспир - в поисках секретов зощенковского слога, [w:] Teksto analize irinterpretacija. Tarptautines konferencijos pranešimai Šiauliai, 1998 m. lapkričio 11-12 d., Šiauliai 1998, s. 142-146.

26. Цитатав структуре «Голубойкниги» Михаила Зощенко, [w:] Взаимодействиелитератур в мировом литературном процессе (проблемы теоретической и исторической поэтики). Материаль международной научной конференции 15-17 апреля 1998 г. в Гродненском государственном университете, в 2 частях, Гродно 1998, часть 1, s. 110-115.

27. О семантике и стилистике синонимических образований в творчестве Михаила Зощенко, „Beiträge zur Slavistik”, t. XXXIX: Textsemantik und Textstilistik. H. Jelitte, J. Wierzbiński (Hrsg.), Frankfurt am Main-Berlin-Bern-New York-Paris-Wien 1999, s. 161-169.

28. Kontaminacja nazw osobowych w utworach Michała Zoszczenki, „Beiträge zur Slavistik”, t. XXXIX: Textsemantik und Textstilistik. H. Jelitte, J. Wierzbiński (Hrsg.), Frankfurt am Main-Berlin-Bern-New York-Paris-Wien 1999, s. 91-100. 
29. Своеобразии черти на Зочченковия стил. Отклонения от езиковия регламент, „Foreign Language Teaching Journal / Чуждоезиково обучение”, Sofia 1999, nr 1, s. 56-62.

30. Typowe i niekonwencjonalne kontrasty leksykalne w utworach Michaiła Zoszczenki (Uwagi wstępne), „Acta Universitatis Lodziensis. Folia Linguistica” 1999, z. 39, s. 95-101.

31. O idiolekcie artystycznym Michała Zoszczenki. Uwag kilka o strukturach kolokwialnych, „Acta Universitatis Lodziensis. Folia Litteraria Rossica” 2000, z. 2, s. 107-116.

32. Komizm a idiolekt artystyczny Michała Zoszczenki, „Stylistyka” 2001, t. X, s. 431-442.

33. Kapitalina, Melor, Turbina - czyli prolegomena do mody imienniczej w porewolucyjnej Rosji, „Przegląd Rusycystyczny” 2001, z. 3, s. 86-93.

34. «Изобретательская семидневка» Владимира Маяковского: словообразовательный и семантический аспекты изучения неологизмов, [w:] Актуальные вопросы изучения русской литературы и культуры, русского языка и методики его преподавания в европейском контексте, под ред. Я. Генцеля, Л. Иохим-Кушликовой и Ф. Листвана, Kraków 2001, s. $255-260$.

35. Синонимичные слова в художественном тексте и в словаре, [w:] Stowo z perspektywy językoznawcy i tłumacza, red. A. Pstyga, K. Szcześniak, Gdańsk 2002, s. 242-247.

36. Zmiany leksykalno-semantyczne w okresie pieriestrojki i głasnosti, „Beiträge zur Slavistik”, t. XLVII: Slovo v tekste, perevode i slovare, Frankfurt am Main-Berlin-Bern-Bruxelles-New York-Oxford-Wien 2002, s. 211-220.

37. Słowo w języku artystycznym Michała Zoszczenki, „Beiträge zur Slavistik”, t. XLVII: Slovo $\mathrm{v}$ tekste, perevode i slovare, Frankfurt am Main-Berlin-Bern-Bruxelles-New York-OxfordWien 2002, s. 199-210.

38. O języku Stalina. Dywersja werbalna, „Beiträge zur Slavistik”, t. XLVII: Slovo v tekste, perevode i slovare, Frankfurt am Main-Berlin-Bern-Bruxelles-New York-Oxford-Wien 2002, s. 183-189 (współautor: T. Stepnowska).

39. Антонимия и антонимичное слово в русском языке (статус, проблемы, аспекты), „Веiträge zur Slavistik", t. XLVII: Slovo v tekste, perevode i slovare, Frankfurt am Main-Berlin -Bern-Bruxelles-New York-Oxford-Wien 2002, s. 221-236.

40. Jan Niecisław Baudouin de Courtenay a najnowsza leksykografia rosyjska (zarys problemu), „Ученые записки Казанского государственного университета”, т. 143: Бодуэн де Куртенэ и современная лингвистика, Казань 2002, s. 69-73.

41. О художественной речи А. П. Чехова. Материаль к словарю антонимов писателя, „Stylistyka" 2002, t. XI, s. 255-268.

42. Uwag kilka o stownictwie rosyjskim w okresie pieriestrojki, [w:] Pragmatyczne aspekty opisu języków wschodniostowiańskich, red. P. Czerwiński, Katowice 2003, s. 77-83.

43. Поэтика и семантическое пространство паремий советского времени, „Stylistyka” 2003, t. XII, s. 279-293.

44. Теоретические проблемы антонимии (взгляд с рубежа веков), „Respectus Philologicus” 4, Kaunas 2003, s. 48-58.

45. О специфике новообразований в произведениях Владимира Маяковского, „Acta Universitatis Lodziensis. Folia Linguistica Rossica” 2003, z. 1, s. 135-144. http://linguisticarossica. cba.pl/file/FOLIA_LINGUISTICA_ROSSICA_1.pdf

46. О воздействующей функиии художественной стилистики, [w:] Лингвистические исследования. Сборник научных работ памяти профессора Герберта Елитте, Казань 2004, s. 173-177 (współautor: K. Popow).

47. Лингвокультурологический аспект изучения художественного текста, [w:] Język rosyjski w konfrontacji z językami Europy w aspekcie lingwokulturoznawczym, pod red. P. Czerwińskiego i H. Fontańskiego, Katowice 2004, s. 265-274. 
48. Композиционно-коммуникативная структура зощенковского текста (на материале рассказа "Обезьяний язык»), [w:] Aktualne problemy semantyki i stylistyki tekstu (studia opisowe i komparatywne), red. J. Wierzbiński, Łódź 2004, s. 119-124.

49. W kwestii słownictwa rosyjskiego i jego semantyki we wspótczesnej leksykografii akademickiej, „Rozprawy Komisji Językowej Łódzkiego Towarzystwa Naukowego”, t. XLIX, 2004, s. 367-378.

50. Impresje o semantyce $i$ stylistyce krótkich form narracyjnych w twórczości Antona Czechowa, [w:] Ogród nauk filologicznych. Księga Jubileuszowa poświęcona Profesorowi Stanisławowi Kochmanowi, red. M. Balowski i W. Chlebda, Opole 2005, s. 683-691.

51. Своеобразие паремиологических изречений, возникиих в советский период, [w:] Jе̨zуk a rzeczywistość. Rusycystyczne studia konfrontatywne, pod red. P. Czerwińskiego i H. Fontańskiego, Katowice 2005, s. 206-212.

52. До питання семантики протиставлених синонімів у російській мові, „Studia Methodologiса", випуск 15, Тернопіль 2005, s. 3-10.

53. О воздействующей функиии художественной стилистики, «Съпоставително езикознание / Сопоставительное языкознание / Contrastive Linguistics», XXX, 2005, кн. 3, s. 110-114 (współautor: K. Popow).

54. Думата в художествения език на Михаил Зошченко, "Български език" 2005, кн. 1, s. $105-111$.

55. Какое разнообразие ликов... или «Толковый словарь названий женщин», "Vergleichende Studien zu den slavischen Sprachen und Literaturen", Bd. 13: Das Russische in zwei sprachigen Worterbuchern. Internationale Fachtagung, Magdeburg, 18.-22.5.2005 (= Русский язык в двуязычных словарях. Международная научная конференция, Магдебург, 18-22 мая 2005 г.) Renate Belentschikow (Hrsg.), Frankfurt am Main-Berlin-Bern-Bruxelles-New York-Oxford-Wien: Lang, 2006, s. 271-281.

56. К вопросу о лингвостилистических особенностях научных текстов, „Acta Universitatis Lodziensis. Folia Linguistica Rossica” 2006, z. 2, s. 149-158.

http://rossica.online.uni.lodz.pl/index.php/content,article, 23

57. On Specific Features of Idiolect in Mikhail Zoshchenko's Literary Works, „Zeszyty Naukowe PWSZ w Płocku, Neofilologia", t. 9, Płock 2006, s. 75-82.

58. Своеобразие зощенковского слога. Отклонения от языкового регламента, „Acta Universitatis Lodziensis. Folia Linguistica Rossica" 2007, z. 3, s. 177-185.

http://rossica.online.uni.lodz.pl/index.php/content,article, 22

59. Энантиосемия и другие проявления контрастной семантики слов в произведениях А.П. Чехова, «Alatoo Academic Studies», Bishkek 2007, Vol. 2, No 2, s. 66-74. Również: «Русский язык и литература в школах Кыргызстана», Бишкек 2007, № 4, s. 70-77.

60. Paremiologia i skrzydlatologia jako nauki integracyjno-interdyscyplinarne $w$ glottodydaktyce, „Zeszyty Naukowe PWSZ w Płocku, Neofilologia”, t. XI: Interdyscyplinarność w glottodydaktyce. Język - literatura - kultura, Płock 2007, s. 29-37.

61. Семантико-культурологический аспект интертекстуальности в художественном тексте, „Acta Universitatis Lodziensis. Folia Linguistica Rossica” 2008, z. 4, s. 179-187. http://rossica.online.uni.lodz.pl/index.php/content,article,29

62. Заметки о семантике метафорических контрастов (на материале юморесок А. П. Чехова), [w:] Problemy semantyki i stylistyki tekstu, red. J. Sosnowski, Łódź 2009, s. 315-321.

63. Intertekstualność z perspektywy interpretacyjnej dzieła literackiego (na materiale utworów Michaiła Zoszczenki), [w:] Świat wartości w literaturze. Tom jubileuszowy dedykowany Profesor Oldze Główko, red. E. Sadzińska i A. Szymańska, Łódź 2009, s. 173-182.

64. Исторический дискурс в литературном тексте Михаила Зощенко (лингвокультурологический аспект), [w:] Филологические традиции в современном литературном и лингвистическом образовании. Сборник научных статей, вып. 8, т. 1, Москва 2009, s. 247-251. 
65. Семантико-стилистические особенности русских загадок, шуток, скороговорок и считалок, [w:] Z zagadnień semantyki i stylistyki tekstu, red. A. Ginter, Łódź 2010, s. 485492.

66. Синтаксическая структура зощенковского сказа (к постановке вопроса), [w:] Rossica Olomuciensia XLVIII. Sborník přispěvků z mezinárodni konference. XX. Olomouckě Dny Rusistu 02.09.-04.09.2009, Olomouc 2009, s. 55-58.

67. Тематические разряды лексики в политическом дискурсе, [w:] La lengua y literatura rusas en el espacio educativo internacional: estado actual y perspectivas (II Congreso Internacional, Granada, 8-10 de septiembre de 2010), t. 2, red. R. Guzmán Tirado, L. Sokolova, I. Votyakova, Granada 2010, s. 2011-2015.

68. К вопросу о когнитивно-культурологическом образе концептов в близкородственных языках, [w:] Интеграчионные прочессы в коммуникативном пространстве регионов. Материаль Международной научной конференщии, г. Волгоград, 12-14 апр. 2010 г., Волгоград 2010, s. 64-70.

69. Общекультурные парадигмы и языковые проиессы в России $X X$ в.: методологический подход, [w:] Филологические традичии в современном литературном и лингвистическом образовании. Сборник научных статей, вып. 9, т. 1, Москва 2010, s. 345-351.

70. Какое разнообразие ликов... или «Толковый словарь названий женщин», [w:] Жизнь продолжается. Ученый, поэт, личность. Памяти Н.П. Колесникова, Ростов-на-Дону 2010, s. $123-128$.

71. Лексический повтор и синтаксический параллелизм в структуре художественных текстов Михаила Зощченко, [w:] Ученые записки Московского гуманитарного педагогического института, т. 9, Москва 2011, s. 343-350.

72. Специфика имен собственных с идеологической маркировкой в русской ономастике, [w:] Десятый международный симпозиум. МАПРЯЛ 2010. Теоретические и методологические проблемы русского языка как иностранного в традииионной и корпусной лингвистике. Доклады и сообщения, Велико-Тырново 2011, s. 398-401.

73. К вопросу о содержании концепта «хлеб» в русской и польской лингвокультурах, [w:] Теоретические и прикладные аспекты изучения семантики и стилистики текста / Теоretyczne i praktyczne aspekty badań semantyki i stylistyki tekstu, red. J. Wierzbiński, Th. Daiber, G. Gochev i I. Zlatev, Łódź 2012, s. 236-246.

74. Топонимические советизмы, связанные с именами Ленина и Сталина, „Acta Universitatis Lodziensis. Folia Linguistica Rossica” 2012, z. 8, s. 103-111. http://linguisticarossica.cba.pl/ file/FOLIA_LINGUISTICA_ROSSICA_8.pdf

75. Семантика и стилистика произведений А. П. Чехова с антонимией в заглавиях, [w]: Язык как система и деятельность - 4, Ростов-на-Дону 2013, s. 160-164.

76. Парадигматическая модель с доминантой радость - горе (на материале сочинений А.П. Чехова и словарей русского языка), „Acta Universitatis Lodziensis. Folia Linguistica Rossica", z. 9: Aktualne problemy semantyki i pragmatyki, red. A. Piasecka, przy współpracy I. Blumental i A. Ginter, 2013, s.127-140.

77. Kodyfikacja stownictwa rosyjskiego w nowszej leksykografii (zarys problemu), [w:] Teksty, podteksty $i$ konteksty. O wspótczesnej polszczyźnie i jej kontaktach z innymi językami słowiańskimi, red. B. Grochala, E. Pałuszyńska, Pruszków k/Lasku 2014, s. 123-137.

78. Семантика и стилистика политических лозунгов, воззваний и цитат советского nepuoda, [w:] W kręgu zagadnień semantyki i stylistyki tekstu, red. A. Piasecka i I. Blumental, Łódź 2014, s. 169-177.

79. Структурно-семантические особенности сложносокращенных слов и аббревиатур, образованных в советский период, „Acta Universitatis Lodziensis. Folia Linguistica Rossica” 2014, z. 10, red. A. Kamińska, 2014, s. 147-154. 
80. Языковая картина дома в русских и польских паремиологических и фразеологических изречениях, [w:] Диалог языков и культур: Россия - Польша, отв. ред. В. С. Картавенко, Смоленск 2015, s. 142-148.

81. Семантическое пространство слова «дом» в русско-польском сопоставлении (на материале словарных толкований и паремиологических изречений) „Acta Universitatis Lodziensis. Folia Linguistica Rossica", z. 11: Dynamika współczesnego języka rosyjskiego. Z zagadnień semantyki, stylistyki i pragmatyki, red. A. Piasecka i I. Blumental, 2015, s. 165-170.

82. Zagadnienie komunikacji tekstowej z perspektywy utworów literackich Michaiła Zoszczenki, [w:] Komunikatywizm - przyszłość nauki XXI wieku, red. G. Habrajska, Łódź 2016 (w druku).

83. Советская действительность сквозь призму анекдота (лингвокультурологический аспект), „Acta Universitatis Lodziensis. Folia Linguistica Rossica”, z. 13, red. K. Ratajczyk, Łódź 2016, s. 121-131.

\section{RECENZJE I ARTYKULY RECENZYJNE}

1. S. Dimitrowa, Isključenija v russkom jazyke, Columbus, Ohio 1994 (246 p.), „Kritikon Litterarum” 23, Mertert/Luxbg. und Oberbillig 1996, Heft 1-4, s. 42-44 (współautor: H.-G. Herrmann).

2. Имре Пачаи, Специфика русской культурной зоны в русской народной речи и фольклоре, Ньиредьхаза 2002 (296 s.), „Respectus Philologicus” 3, Kaunas 2003, s. 161-162.

3. О запретном - Aurika Czerwinsky, Margarita Nadel-Czerwinska, Piotr Czerwinski, ,,Schriftenreihe Philologia", Bd. 47: Metaphern des russischen sexuellen Ego. Einpsycholinguistisches Wörterbuch des aktuellen Sprachgebrauchs. Jürgen Hartung (Hrsg.), Hamburg: Verlag Dr. Kovač, 2001 (342 s.), „Respectus Philologicus“6, Kaunas 2004, s. 177-180.

4. Semantyka rosyjskich struktur morfosyntaktycznych $z$ datiwem $w$ aspekcie lingwistyki kognitywnej (artykuł recenzyjny: Beata Rycielska, Celownik rosyjski. Studium kognitywne. Uniwersytet Szczeciński. Rozprawy i studia, t. (DCCXIII) 639, Szczecin: Wydawnictwo Naukowe Uniwersytetu Szczecińskiego, 2007, 292 s.), «Вестник Волгоградского государственного университета» 2008, серия 2: Языкознание, № 2 (8), s. 158-168.

5. Modele komunikacyjne $z$ parenteza $w$ tekście literackim (artykuł recenzyjny: Tatiana Kwiatkowska, Функиии вводных и вставных конструкиий в художественном повествовании (на материале романа Н.С. Лескова «На ножах». Prace Naukowe Uniwersytetu Ślaskiego w Katowicach $n$ r 2472, Katowice: Wydawnictwo Uniwersytetu Ślaskiego, 2007, 128 s.), „Studia Methodologica”, випуск 26, Тернопіль 2009, s. 154-158.

6. Status nowego słownictwa rosyjskiego w opracowaniach leksykograficznych (artykuł recenzyjny: Маргарита Надель-Червинская, Новая лексика в русских толковых словарях конца XX-начала XXI веков. Prace Naukowe Uniwersytetu Śląskiego w Katowicach nr 2406, Katowice: Wydawnictwo Uniwersytetu Śląkiego, 2006, 172 s.), „HORYZONTY. Pismo literacko-artystyczne”, nr 22, Racibórz 2009, s. 71-77. Również w: „Acta Universitatis Lodziensis. Folia Linguistica Rossica” 2010, z. 6, s. 201-208.

7. O rosyjskich konstrukcjach bezosobowych z celownikiem w ujęciu kognitywnym (Beata Rycielska, Marzena Rycielska, Obrazowanie w języku. ,Lancetnik bez głowy” i celownik rosyjski, Stupsk: Wydawnictwo Naukowe Akademii Pomorskiej, 2008, 98 s.), „Acta Universitatis Lodziensis. Folia Linguistica Rossica" 2009, z. 5, s. 205-207.

8. Koncept ,, ангел / aniot” w językowo-kulturowym obrazie świata (artykuł recenzyjny: Ewa Straś, Ангел / Aniol в русско-польском сопоставлении: семантико-этнокультурныии аспект, Тернополь: Крок, 2013, 352 s.), „Acta Universitatis Lodziensis. Folia Linguistica 
Rossica”, z. 11: Dynamika współczesnego języka rosyjskiego. Z zagadnień semantyki, stylistyki i pragmatyki, red. A. Piasecka i I. Blumental, 2015, s. 159-164.

9. Studium o języku i poznaniu. Rzeczowniki wspólnorodzajowe $w$ aspekcie porównawczym (artykuł recenzyjny: Beata Rycielska, Język i poznanie. Rzeczowniki wspólnorodzajowe w języku rosyjskim w porównaniu z polskim, Łódź: Primum Verbum, 2015, 86 s.), „Acta Universitatis Lodziensis. Folia Linguistica Rossica”, z. 13, red. K. Ratajczyk, Łódź 2016 Łódź 2016, s. 133-138.

\section{TEZY, SZKICE, STRESZCZENIA, KOMUNIKATY}

1. «Они сражались за Родину» М. А. Шолохова, «Комсомолец», Ростов-на-Дону 1975, № 96, s. 3 (тезисы: обсуждение фильма С. Бондарчука по одноименной повести М. Шолохова).

2. Проблемы семного анализа антонимо-синонимических отношений, «Молодой журналист», Ростов-на-Дону 1982, № 4 (165), s. 3 (материалы ежегодной конференции аспирантов и молодых ученых филологического факультета РГУ).

3. Antonimo-sinonimičeskie otnošenija v leksike (na materiale chudožestvennych proizvedenij A.P. Čechova), „Biuletyn Slawistyczny” XII-XIII. Tezy rozpraw doktorskich. Językoznawstwo, Warszawa 1988, s. 109-112 (Polska Akademia Nauk. Instytut Słowianoznawstwa).

4. Zmiażḋony prześmiewca czyli słów kilka o Michaile Zoszczence, „Przekrój” 1993, nr 19, s.18-19 (współautor: T. Stepnowska).

5. Świadomość językowa bohaterów Michaiła Zoszczenki a kwestia cudzoziemców, [w:] Streszczenia odczytów: XII Konferencja Międzynarodowej Komunikacji Językowej oraz Sympozjum Sekcji Indoeuropejskiej Polskiego Towarzystwa Filologicznego nt. „Idee, działalność i dorobek niezależnych stowarzyszeń uniwersyteckich: Ausra i Philokaloi”, Łódź 25-27 listopada 1994, Łódź 1995, s. 14-15.

6. Uwielbiany i pogardzany czyli żywa legenda Michaiła Zoszczenki, „Literatura” 1998, nr 4, s. 27-29 (współautor: T. Stepnowska).

7. O profesorze Sergiuszu Kułakowskim (1892-1949) - nestorze polskiej rusycystyki i pierwszym tódzkim rusycyście uniwersyteckim, „Zeszyty Naukowe PWSZ w Płocku, Neofilologia”, t. 7, Płock 2005, s. 107-116.

8. Językoznawstwo rusycystyczne w Uniwersytecie Łódzkim (historia, współczesność i perspektywy badań), „Rozprawy Komisji Językowej Łódzkiego Towarzystwa Naukowego”, t. L, 2005, s. 201-208.

9. Реалізація болоньських принципів у реаліях польської вищої освіти, «Університет». Історико-філософський журнал. Видається Київським славістичним університетом, Київ 2005, № 6, s. 89-94.

10. Толковый словарь названий женщин (составитель Н. П. Колесников). Москва 2002, «Сьпоставително езикознание / Сопоставительное языкознание / Contrastive Linguistics», XXXI, 2006, кн. 1, s. 152-153.

\section{WSTĘPY, SPRAWOZDANIA, BIOGRAMY}

1. Vorwort, „Beiträge zur Slavistik“, t. XLVII: Slovo v tekste, perevode i slovare, Frankfurt am Main-Berlin-Bern-Bruxelles-New York-Oxford-Wien 2002, s. 11 (współautor: K.Bajor). 
2. Prof. dr hab. Kazimierz Bajor, [w:] 50 lat Wydziału Filologicznego Uniwersytetu Łódzkiego (1952-2002); zob. rozdział: Sylwetki samodzielnych pracowników naukowych, Łódź 2002, s. $53-54$.

3. Forum slawistów z Polski, Rosji, Ukrainy, Litwy i Wegier, „Kronika”. Pismo Uniwersytetu Łódzkiego 2003, nr 5, s. 36-37.

4. Od Redaktora, „Acta Universitatis Lodziensis. Folia Linguistica Rossica” 2003, z. 1, s. 5-6.

5. Lenkijos, Rusijos, Ukrainos, Lietuvos ir Vengrijos slavistu forumas, „Respectus Philologicus” 5, Kaunas 2004, s. 233-234.

6. Przedmowa, [w:] Aktualne problemy semantyki i stylistyki tekstu (studia opisowe i komparatywne), red. J. Wierzbiński, Łódź 2004, s. 3-4.

7. Wyksztatcił wiele pokoleń rusycystów. Profesor Kazimierz Bajor (1931-2006), „Kronika”. Pismo Uniwersytetu Łódzkiego 2006, nr 4, s. 28-29.

8. Profesor Kazimierz Bajor (1931-2006), [w:] Sprawozdania z czynności i posiedzeń naukowych ŁTN, t. LX, Łódź 2006, s. 104-109.

9. Od Redaktorów / Von der Herausgebern, „Acta Universitatis Lodziensis. Folia Linguistica Rossica" 2007, z. 3, s. 3 i 5 (współautor: M. Wingender).

10. Międzynarodowa Olimpiada Języków Stowiańskich, Literatury i Kultury w Kijowie. Medalowe miejsca łodzian, „Kronika”. Pismo Uniwersytetu Łódzkiego 2008, nr 4, s. 7.

11. Pamięci Profesora Kazimierza Bajora (1931 - 2006). W rocznice pożegnania, „Acta Universitatis Lodziensis. Folia Linguistica Rossica” 2009, z. 5, s. 5-8.

12. Bibliografia prac Prof. $z w$. dr. hab. Kazimierza Bajora, „Acta Universitatis Lodziensis. Folia Linguistica Rossica" 2009, z. 5, s. 9-14.

13. Stowo wstępne / Vorwort, „Acta Universitatis Lodziensis. Folia Linguistica Rossica” 2010, z. 6, s. 3-6 (współautor: Th. Daiber).

14. Od redakcji, [w:] Теоретические и прикладные аспекты изучения семантики и стилистики текста / Teoretyczne i praktyczne aspekty badań semantyki i stylistyki tekstu, Łódź 2012, s. 5-6.

15. Międzynarodowe forum filologów, „Kronika”. Pismo Uniwersytetu Łódzkiego 2012, nr 1, s. $17-18$.

16. Искренне горжусь моим учителем! (Воспоминания о профессоре Людмиле Алексеевне Введенской), [w]: Язык как система и деятельность - 4, Ростов-на-Дону 2013, s. 10-12.

17. IN MEMORIAM. Светлой памяти Константина Попова!, „Болгарская русистика” 2015, № 3-4, s. 303-305.

\section{PRACE PRZEKLADOWE}

\section{a) $\mathrm{Z}$ języka polskiego na rosyjski}

1. Artykuł Pawła Spodenkiewicza: Ежи Стемповского La Terre Imaginee, [w:] Национализм в Центральной и Восточной Европе. Материаль международной конференции 16-18 сентября 1992 2., Łódź 1992, s. 67-70.

2-11. Streszczenia artykułów do ZN UŁ: 5 pozycji w: „Acta Universitatis Lodziensis. Folia Linguistica" 1996, z. 35: Beata Burska, s. 15-16; Urszula Dzióbałtowska-Chciuk, s. 26-27; Teresa Świętosławska, s. 37; Krystyna Wojtczuk, s. 55; Danuta Zawilska, s. 62 oraz 5 pozycji w „Acta Universitatis Lodziensis. Folia Linguistica” 1998, z. 38: Piotr Bąk; Anna Magdalena Fendor, s. 17-18; Katarzyna Jachimowska, s. 31; Ewa Szkudlarek, s. 95-96; Sławomira Tomaszewska, s. 103. 


\section{b) $\mathrm{Z}$ języka rosyjskiego na polski}

1-3. 3 szkice literackie Konstantina Popowa: Świeca, „Odgłosy” 1991, nr 25 (1710) z 10.XI., s. 8; też w: „Orthodoxia. Przegląd Prawosławny” 1993 (Białystok), nr 11 (101) z XI., s. 8-9 i 10; Krzyż, „Orthodoxia. Przegląd Prawosławny” 1993 (Białystok), nr 12 (102) z XII., s. 26-27; Modlitwa, „Tygodnik Zgierski” 1994: (cz. 1) nr 26 (137) z 30.VI., s. 4; (cz. 2) nr 27 (138) z 7.VII., s. 3; (cz. 3) nr 28-29 (139-140) z 14.VII., s. 4. (Zob. notatkę na temat ostatniego szkicu w nr. 32-33 (143-144) z 11.VIII.1994 r. na s. 2).

4. Streszczenie artykułu Konstantina Popowa w: „Acta Universitatis Lodziensis. Folia Linguistica" 1998, z. 38, s. 65.

5-7. 3 artykuły hasłowe Aleksandra Zwoznikowa do słownika: Idee w Rosji. Mentalność rosyjska. Słownik. Opracował i zredagował Andrzej Lazari (Interdyscyplinarny Zespół Badań Sowietologicznych Uniwersytetu Łódzkiego), Katowice 1995 (Wyd. „Śląsk”): Дорогa /nymb - Droga. Droga żyсіа (s. 26); Подвиг/подвижничество - Czyn podniosty (s. 62-63); Справедливость - Sprawiedliwość, prawość (s. 91). Również w: Idee w Rosji / Идеи в Poccuи / Ideas in Russia. Leksykon rosyjsko-polsko-angielski pod red. Andrzeja de Lazari: t. 1, Warszawa 1999, s. 314: Подвиг / Подвижничество - Czyn podniosty / Podwiżniczestwo (Wyd. Naukowe Semper); t. 3, Łódź 2000, s. 138: Дорога - Путь - Droga (Wyd. Ibidem); t. 5, Łódź 2003, s. 294: Справедливость - Sprawiedliwość, prawość (Wyd. Ibidem). 